\title{
Teaching Video NeuroImages: Figure 8 head- shaking stereotypy in rhombencephalosynapsis
}

Andrea Accogli, MD, and Myriam Srour, MD, PhD

Neurology ${ }^{\circledR}$ 2018;90:e1832-e1833. doi:10.1212/WNL.0000000000005531

\section{Correspondence}

Dr. Srour

myriam.srour@mcgill.ca

Figure Imaging
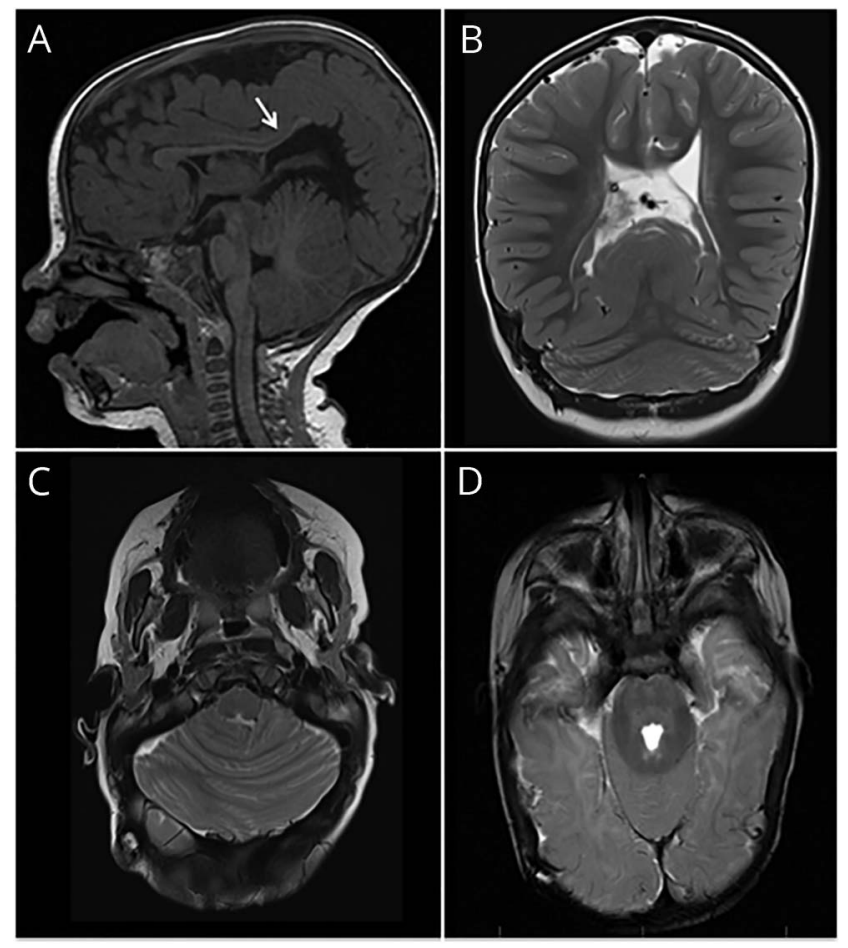

Midline sagittal T1-weighted image (A) reveals hemispheric cerebellar lobulation pattern and outstretched posterior corpus callosum (arrow) due to interhemispheric cyst. Coronal (B) and axial (C) T2-weighted images show vermis agenesis and fusion of cerebellar hemispheres with continuity of folia across the midline. Axial T2-weighted image (D) demonstrates a keyhole-shaped 4th ventricle.

A 4-year-old boy had congenital hydrocephalus due to aqueductal stenosis and was treated with a ventriculoperitoneal shunt at birth. Brain MRI revealed absence of the cerebellar vermis with continuity of the cerebellar hemispheres across the midline, consistent with rhombencephalosynapsis (figure). ${ }^{1}$ He has mild global developmental delay. Neurologic examination revealed absent nystagmus, oculomotor apraxia, dysmetria, or ataxia. Since the age of 1 , he has had stereotyped head movements consisting of rhythmic figure 8 and side-to-side shaking (video). This distinctive stereotypy is reported in $85 \%$ of individuals with rhombencephalosynapsis. ${ }^{2}$ Its presence should alert clinicians of possible underlying rhombencephalosynapsis or other posterior fossa malformations.

\section{Author contributions}

Andrea Accogli: drafting/revising the manuscript, study concept or design, analysis or interpretation of data, accepts responsibility for conduct of research and final approval, acquisition of data, study

\section{MORE ONLINE}

\section{$\odot$ Video}

$\rightarrow$ Teaching slides:

links.lww.com/WNL/A451

From the Departments of Pediatrics (A.A., M.S.) and Neurology and Neurosurgery (M.S.), McGill University, Montreal, Canada; Istituto Giannina Gaslini (A.A.), Genova; and Università degli Studi di Genova (A.A.), Italy.

Go to Neurology.org/N for full disclosures. Funding information and disclosures deemed relevant by the authors, if any, are provided at the end of the article. 
supervision. Myriam Srour: drafting/revising the manuscript, study concept or design, accepts responsibility for conduct of research and final approval, acquisition of data, study supervision.

\section{Acknowledgment}

The authors thank the parents for their contribution to this study.

\section{Study funding}

No targeted funding reported.

\section{Disclosure}

The authors report no disclosures relevant to the manuscript. Go to Neurology.org/N for full disclosures.

\section{References}

1. Ishak GE, Dempsey JC, Shaw DW, et al. Rhomboencephalosynapsis: a hindbrain malformation associated with incomplete separation of midbrain and forebrain, hydrocephalus and a broad spectrum of severity. Brain 2012;135: 1370-1386.

2. Tully HM, Dempsey JC, Ishak GE, et al. Persistent figure-eight and side-to-side head shaking is a marker for rhombencephalosynapsis. Mov Disord 2013;28:2019-2023. 


\section{Neurology}

\section{Teaching Video NeuroImages: Figure 8 head-shaking stereotypy in rhombencephalosynapsis \\ Andrea Accogli and Myriam Srour \\ Neurology 2018;90;e1832-e1833 \\ DOI 10.1212/WNL.0000000000005531}

\section{This information is current as of May 14, 2018}

\section{Updated Information \& Services}

\section{References}

Subspecialty Collections

Permissions \& Licensing

Reprints including high resolution figures, can be found at: http://n.neurology.org/content/90/20/e1832.full

This article cites 2 articles, 0 of which you can access for free at: http://n.neurology.org/content/90/20/e1832.full\#ref-list-1

This article, along with others on similar topics, appears in the following collection(s):

All Movement Disorders

http://n.neurology.org/cgi/collection/all_movement_disorders Developmental disorders

http://n.neurology.org/cgi/collection/developmental_disorders Motor Control

http://n.neurology.org/cgi/collection/motor_control MRI

http://n.neurology.org/cgi/collection/mri

Information about reproducing this article in parts (figures,tables) or in its entirety can be found online at:

http://www.neurology.org/about/about_the_journal\#permissions

Information about ordering reprints can be found online:

http://n.neurology.org/subscribers/advertise

Neurology ${ }^{\circledR}$ is the official journal of the American Academy of Neurology. Published continuously since 1951 , it is now a weekly with 48 issues per year. Copyright @ 2018 American Academy of Neurology. All rights reserved. Print ISSN: 0028-3878. Online ISSN: 1526-632X.

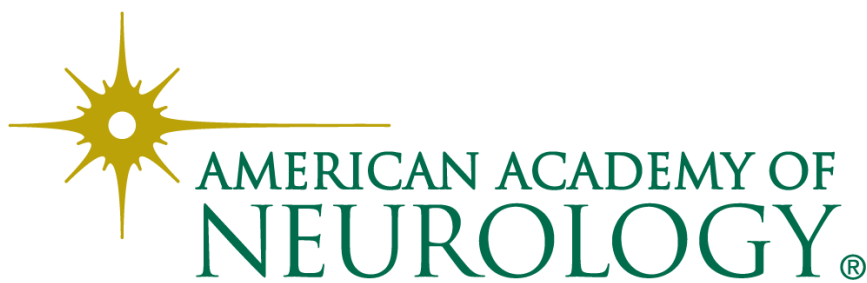

